\title{
Jiří Němec, Eduard Winter 1896-1982. Zpráva o originalitě a přizpůsobení se sudetoněmeckého historika
}

\section{Brno 2017, 380 stran, ISBN 978-80-210-8808-5}

Sepsání životopisu historika, který byl záhadným i pro východoněmeckou Stasi, byl pro autora recenzované publikace jistě nelehký úkol. Oprávněně skepticky přistupuje k Winterovým vlastním autobiografickým textům, jejichž výpověd’ se liší nejen podle doby vzniku textu, ale i podle předpokládaného publika. Analýze autobiografických textů je také věnována samostatná kapitola knihy. Kniha je rozdělena na několik kapitol, první z nich se zabývají Winterovou činností za první republiky a jeho myšlenkovým zakotvením. Tyto pasáže jsou zdaleka nejpropracovanější z celé knihy, autor podrobně rozebírá řadu Winterových textů, snaží se najít jeho myšlenková východiska, zejména pak jeho vztah k náboženství a katolické církvi. Zabývá se jeho prvními bolzanovskými studiemi. Věnuje se i Winterově činnosti ve sdružení Staffelstein. Už zde je nastíněn rozsah Winterových kontaktů, které zahrnují širokou škálu názorových i náboženských proudů, zakotvenost v českoněmeckém prostředí a velmi dobré vztahy s českou stranou. Z textu vyplývá, že postupně měl jako katolický kněz nejvíce problémů právě s katolickou církví, a to z různých důvodů. Např́klad byl již roku 1936 pražským arcibiskupem Karlem Kašparem pokárán, že se jako děkan německé teologické fakulty účastnil instalační přednášky děkana Husovy československé evangelické fakulty bohoslovecké Ferdinanda Hrejsy. Němec poukazuje na to, že na základě těchto širokých kontaktů a rozsáhlých společenských aktivit byl Winter vnímán na přelomu let 1939/40 jako nedůvěryhodný jak katolickou církví, tak německými správními úřady.

Další dvě kapitoly se zabývají Winterovou činností v rozmezí let 1938 a 1945. Roku 1940 se Winter definitivně rozešel s katolickou církví, byl exkomunikován a posléze přešel z německé teologické fakulty na filozofickou, což se neobešlo bez problémů. Poměrně podrobně je vylíčen př́klon k nacistické ideologii a spolupráce s vrcholnými představiteli nacistické vědy na německé filozofické fakultě (Hans Joachim Beyer) i spolupráce s SD. Není pominuta ani rozsáhlá činnost v rámci Heydrichovy nadace či vydání rozsáhlé monografie o josefinismu. Bez zajímavosti není ani Winterova účast v kolektivu plánujícím vydání univerzitních dějin v jubilejním roce 1948. Zvláštnost Winterovy osobnosti ukazuje Němec na tom, že ani jako přední nacistický vědec si neuzavřel cestu k českým kolegům. Roku 1943 např́klad varoval zaměstnance Státního ústavu historického před možnými prohlídkami a před Heinzem Zatschekem či o rok dříve nabízel svou pomoc Z. Kalistovi.

V roce 1945 odjíždí Winter, který se vyhnul internaci i hromadným odsunům, do Rakouska, kam již před koncem války evakuoval svou početnou rodinu. Ve Vídni se neúspěšně pokusil navázat na svoji univerzitní kariéru - problém měl zřejmě v katolickém Rakousku po svém odchodu z církve, protože vždy někdo mohl poukázat na jeho nacistickou minulost (včetně členství v NSDAP, které se snažil zamlčovat). Roku 1947 tudíž přesídlil do Halle a odtud pak jako profesor východoevropských dějin na Humboldtovu univerzitu do Berlína, kde působil až do svého penzionování roku 1965. Winter zde navázal na svůj zájem o ruské dějiny, kterým se začal věnovat už za války v Praze, byt' v poválečném východním Německu zcela jinak konotované. Jeho hlavním tématem se stává vztah německo-slovanský, přičemž výslovně odmítá německou kulturní nadřazenost, typickou pro východní studia předchozí doby. Winter v době svého berlínského působení vychoval celou řadu 
žáků a stal se jedním z prominentních historiků NDR, členem německé akademie věd, kde pod jeho vedením fungovalo oddělení pro dějiny vědy a vědeckých vztahů, zvláště německo-slovanských. A to přesto, že Winter nadále zůstával rakouským občanem, vlastnícím dům v Rakousku, kam pravidelně jezdil. V této době byl vnímán jako „nejvýraznějši představitel ,buržoazního 'dějepisectví, který přispěl k rozvoji marxistického dějepisectví $v N D R$.“ Je třeba zmínit, že pro poválečné období již kniha nepřináší tak důkladné analýzy Winterových textů, byt’ se snaží vystopovat myšlenkové zvraty Wintera jako člověka i historika. Nutno dodat, že mnoho záhad ve Winterově životě zůstává. Nakonec i autor knihy se zamýšlí nad tím, která z Winterových vyjádření byla jen nutným vyjádřením souhlasu s mocí a která byla míněna vážně. Ukazuje, že opravdu není jednoduché a často ani možné to zjistit i proto, že Winterovy vlastní životopisy či úryvky autobiografických textů tomu také př́liš nepomáhají. Závěrem je třeba dodat, že Němcova kniha je knihou velmi podnětnou, založenou na dlouholetém výzkumu, a je proto škoda, že neprošla důkladnějším redakčním zpracováním. Kniha tak zbytečně obsahuje mnoho překlepů či jazykových chyb, které mohly být lehce odstraněny.

Jana Ratajová doi: $10.14712 / 23365730.2021 .11$

\section{Marek VIha - Josef Šaur a kol., Kalendárium Masarykovy univerzity 1919-2019 \\ Masarykova univerzita, Brno 2019, 247 s., ISBN 978-80-210-9116-0}

Publikace kolektivu historiků ${ }^{1}$ vzešlých z Masarykovy univerzity přináší pohled na 100 let dějin této významné moravské vědeckopedagogické instituce. Cílem autorů bylo předložit $\mathrm{k}$ tomuto významnému výročí publikaci atraktivní nejen pro vážné zájemce o dějiny univerzity a vzdělanosti, města Brna, Moravy, ale především pro čtenáře populárně naučné literatury.

Kalendárium Masarykovy univerzity je sestaveno chronologicky, nechybí ale přesahy a exkurzy k jednotlivým osobnostem a událostem. Vedle př́iběhu samotné Masarykovy univerzity jsou přibliženy proměny vysokého školství a univerzitního prostředí obecně, včetně životních podmínek profesorů a studentů.

Kniha začíná tradicemi moravské vzdělanosti a v souvislosti s ní je zmíněna zejména činnost humanistů Jednoty bratrské a J. A. Komenského. Na Moravě vznikla sice univerzita již v roce 1566 v Olomouci, ta však sloužila jako instituce vyššího vzdělání, na které nefungovaly všechny fakulty. V 50. letech 19 století byla nakonec zrušena. Založení plnohodnotné moravské univerzity dlouho bránil zejména sílící nacionalismus. Mnohaleté úsilí českých vědců a politiků i nejširš́i veřejnosti bylo završeno až 28. ledna 1919, kdy univerzita o čtyřech fakultách (přírodovědecká, právnická, filozofická, lékařská) konečně vznikla.

Během prvních let existence se Masarykova univerzita zařadila k významným střediskům vzdělávání a kulturního života na Moravě a v Brně. Univerzita na druhou stranu zejména v době hospodářské krize zápasila s finančními i prostorovými problémy a s tlaky

1 Marek Vlha, Josef Šaur, Lukáš Fasora, Jiří Hanuš, Jana Černá, Anna Pečinková. 